\title{
Arquivos Analíticos de $\mathbf{P}_{\text {olíticas }} \mathbf{E}_{\text {ducativas }}$
}

\author{
Revista Acadêmica avaliada por pares \\ Editor: Sherman Dorn \\ College of Education \\ University of South Florida
}

\author{
Editores Associados para Espanhol y Português \\ Gustavo Fischman \\ Arizona State University \\ Pablo Gentili \\ Laboratório de Políticas Públicas \\ Universidade do Estado do Rio de Janeiro
}

Volume 16

Número 2

Janeiro 15, 2008

ISSN 1068-2341

\section{Mídia, juventude e educação: modos de construir o "outro" na cultura}

\section{Rosa Maria Bueno Fischer Universidade Federal do Rio Grande do Sul, Brasil}

Citação: Bueno Fischer, R.M. (2008) Mídia, juventude e educação: modos de construir o "outro" na cultura. Arquivos Analíticos de Políticas Educativas, 16(2). Recuperado [fecha] de http://epaa.asu.edu/epaa/v16n2

\section{Resumo}

Neste artigo, o propósito é discutir um projeto de pesquisa realizado de 2002 a 2005, em Porto Alegre, Brasil, com um grupo de 90 estudantes, cujos depoimentos tratam de diferentes produtos da mídia, especialmente a televisão, e que têm como objeto questões sobre juventude. A partir dos dados coletados através da escuta de estudantes de escolas públicas e privadas e do estudo de produtos televisivos, selecionou-se um tema principal para a análise dos modos de existência jovem: a construção do "outro" nos meios de comunicação e a relação desses grupos com as diferenças sociais, econômicas, geracionais, raciais e étnicas, de gênero e de aparência física. Com apoio em Michel Foucault, particularmente nos conceitos de normalidade, anormalidade e modos de subjetivação, e também em Hannah Arendt e suas elaborações sobre vida pública e vida privada, discutimos as formas pelas quais a sociedade do espetáculo e da

\section{(c)}

SOMRERIGHISRESEREDD O Copyright e retido pelo/a o autor/a (ou primeiro co-autor) que outorga o direito da primeira publicação à revista Arquivos Analíticos de Políticas Educativas. Más informação da licença de Creative Commons encontram-se em http://creativecommons.org/licenses/by-nc-nd/2.5. Qualquer outro uso deve ser aprovado em conjunto pelo/s autor/es e por AAPE/EPAA. AAPE/EPAA é publicada em colaboração por Mary Lou Fulton College of Education da Arizona State University e pelo College of Education at University of South Florida. Os textos publicados em AAPE são indexados por H.G. Wilson \& Co. e pelo Directory of Open Access Journals (http://www.doaj.org). Contribua com comentários e sugestões a Fischman@asu.edu e/ou pablo@lpp-uerj.net. 
imagem opera na nomeação e na construção dos "outros jovens". Utilizamos ainda conceitos como os de diferença e de alteridade, recorrendo principalmente aos estudos de Carlos Skliar, entre outros.

Palavras-chave: mídia, juventude, televisão, diferença, normalidade, cultura.

\title{
Media, youth, and education: modes of constructing the "other" in culture
}

\begin{abstract}
The aim of this paper is to discuss a research project conducted between 2002-2005 in Porto Alegre, Brazil. The focus was exploring how a group of 90 students perceived media's discourse - especially television - about "youth." Through the analysis of the discourse of both media and students, the research team selected a main theme for inquiry: the construction of the "other" in the mass media and the perception of differences among these groups in relationship to social, economic, generational, racial, ethnic, and physical appearance dynamics. This research uses Foucaltian categories of analysis, specifically the concepts of normality, abnormality, and modes of subjectivity, and Hannah Arendt conceptualization about public and private spheres - which allows for discussion of the multiple performances and images operating through media mechanisms. This work also uses other concepts like difference and alterity, follwoing Carlos Skliar studies.
\end{abstract}

Key words: media, youth, television, difference, normality, culture.

\section{Mídia, juventude e educação: modos de construir o "outro" na cultura}

Neste texto ${ }^{1}$, proponho-me a discutir alguns aspectos das novas configurações dos espaços públicos e privados, em nossa sociedade, e que dizem respeito a modos de existência dos diferentes grupos sociais, propiciadas pela experiência cotidiana sobretudo com a televisão e as novas mídias digitais. Tal discussão é feita tendo como ponto de partida dados de uma investigação em que o centro das atenções é o diálogo entre a análise de produtos midiáticos e o depoimento de jovens estudantes, a respeito de sua relação com os meios de comunicação. Trato de produtos destinados ao público juvenil, especialmente pelos canais de TV aberta e a cabo, no Brasil, problematizando o discurso da mídia e os modos de existência jovem nele propostos, em contraponto com a experiência de grupos de estudantes, diante dos materiais midiáticos que lhes são oferecidos. Apóio-me em autores cujas ferramentas teóricas permitem pensar os dados coletados, particularmente a partir de conceitos como os de normalidade e anormalidade, em Michel Foucault; alteridade e diferença, em Jacques Derrida e Carlos Skliar; esferas pública e privada, em Hannah Arendt, com o intuito de problematizar questões contemporâneas sobre os modos de produção e circulação de sentidos, a respeito das concepções de vida pública e vida privada, bem como da constituição de si e do outro - temas extremamente relevantes para o campo da educação.

Parto do pressuposto de que existiria uma figura desejável e desejada, presente nas diversas mídias: na cena da telenovela, na foto do outdoor, no desfile de moda, nas páginas do caderno de vida e saúde do jornal, no programa de debates da TV, na reportagem sobre sexo e drogas, na fala do personagem de humor que mimetiza o candidato à universidade, no congresso

${ }^{1}$ Os resultados da pesquisa, realizada com apoio do CNPq, foram apresentados no 2007 AERA Annual Meeting, em Chicago, USA, no Painel "Media and Educational Politics and Policies" Este texto é uma versão ampliada do artigo "Mídia e educação: em cena, modos de existência jovem", publicado em Educar em revista (FISCHER, 2005a). 
sobre prevenção à AIDS, ao HIV, à gravidez precoce, no seminário sobre usos da Internet, na revista feminina que divulga o corpo belo e esculpido, na matéria jornalística sobre crimes e violência. Haveria de fato um "outro" que, desde os anos 50 do século XX, segundo escreve Eric Hobsbawm (1995), assume um lugar privilegiado nos espaços da cultura. Esse outro é o jovem, lugar de chegada, lugar de permanência, paradoxalmente lugar de eternidade: há muito tempo conhecemos histórias que remetem ao mito da "eterna juventude", tema que não cessa de habitar fantasias de imortalidade, e que ocupa posição de destaque nunca antes imaginado, nestes tempos de proliferação, instantaneidade e multiplicação de imagens, graças aos avanços diários das novas tecnologias de informação e comunicação. Esse "outro" é o jovem, que não cansamos de nomear, de narrar, a quem não permitimos qualquer sossego, gente cujo mistério queremos a todo o custo explorar, desvendar, expor.

Trato aqui, portanto, de questões educacionais referentes a uma faixa da população que, no Brasil, chega a aproximadamente 35 milhões de pessoas (jovens de 15 a 25 anos), e sobre a qual disseminam-se inúmeros "ditos" já cristalizados como senso comum, associando juventude a violência, a consumismo, apatia, gravidez precoce, sexo irresponsável, e assim por diante ${ }^{2}$. A idéia é, conforme a pesquisa que realizamos de 2002 a $2005^{3}$, expor e discutir, a partir das falas dos próprios jovens, sua condição de alvo desses ditos do senso comum, que circulam em vários lugares sociais, sobretudo nos meios de comunicação - esse lugar de construção e veiculação de "verdades". Ao mergulhar na temática "vida jovem e TV", foi realizada a seleção e a análise de como a cultura contemporânea, nesse meio específico (a TV), tem proposto, delineado, situado e sugerido formas de existência "coletiva" aos grupos jovens, por meio dos produtos a eles oferecidos. Considerando os dados dos materiais midiáticos e dos depoimentos dos jovens, temse um rico conjunto de dados que nos incentivam a dialogar com autores como Hannah Arendt (2000) e Richard Sennett (2001), por exemplo, a respeito de concepções sobre vida pública e privada, que marcam modos de ser da subjetividade ocidental em nosso tempo.

\section{Diferentes Nomeações De Grupos Jovens}

Como a mídia narra os espaços públicos e os privados? Como se refere, por exemplo, à "criação" de algo que seja produzido "em grupo"? Como as diferenças - de raça, etnia, geracionais, de gênero, de condição social e econômica - são mostradas nos espaços midiáticos, especialmente a TV, considerando aspectos sociais e individuais do cotidiano de grupos jovens? De que modo essas construções são percebidas e também narradas por esses mesmos grupos? Perguntas como essas orientaram a pesquisa de que trato aqui. Diante da amplitude dos dados, selecionei neste artigo um tópico para desenvolver mais demoradamente. A proposta é discutir, teoricamente, valendo-me dos depoimentos dos estudantes, o tema da construção do "outro" na mídia: como se dá, entre grupos de estudantes, universitários e de Ensino Médio, de diferentes camadas sociais, e na cidade de Porto Alegre (Rio Grande do Sul, Brasil), a nomeação daquele que "é diferente de mim"?

2 Observações semelhantes encontram-se em vários estudos recentes sobre juventude. Ver, a propósito, Abramo; Freitas; Sposito (orgs.), 2002. Ver também Abramo (2005).

3 Refiro-me à pesquisa "Mídia, juventude e reinvenção do espaço público". Basicamente, trabalhamos com dois tipos de dados: transcrição de aproximadamente 50 horas de gravações de programas de TV destinados ao público de 15 a 25 anos ou que fazem referência explícita a esse grupo (por exemplo, a novela teen Malbação, da Rede Globo, e outros materiais televisivos, endereçados a jovens, peças publicitárias, trechos de telejornais, com notícias e reportagens cujo centro era a figura jovem; e dados referentes a 23 encontros com seis grupos de recepção (estudantes de Ensino Médio de duas escolas públicas e uma particular e de uma escola pública de educação de jovens e adultos, além de jovens de dois cursos - Comunicação e Pedagogia - de uma Universidade Federal, aos quais foram exibidos trechos dos programas analisados, somando um total de 90 participantes). (Fischer, 2005). 
Parto do pressuposto de Michel Foucault (1986; 1990; 1995; 2004), de que "a verdade é deste mundo"; ou seja, de que somos permanentemente constituídos por diferentes discursos, e nos tornamos sujeitos de certas verdades, no interior de determinados regimes de poder. $\mathrm{Na}$ concepção foucaultiana, porém, o fato de nos tornarmos sujeitos de verdades não impede - pelo contrário, supõe - que os sujeitos também se constituem a si mesmos, para além daquilo que lhes é oferecido como norma ou regra de vida. Neste texto, levo em conta essa idéia complexa da produção de modos de existência na cultura (especialmente pela ação dos meios de comunicação), articulando-a a outros conceitos relativos à construção dos "outros" e das diferenças em nossa sociedade (Larrosa, 2004; Costa, 2004; Kehl, 2004; Foucault, 2001; Skliar, 2003).

Em pesquisas anteriores (Fischer, 2000; 2001), ocupei-me em examinar "técnicas de si" em produtos da mídia, descrevendo como certas estratégias de linguagem da TV se mostram estreitamente conectadas com toda uma tecnologia de produzir o sujeito contemporâneo, no sentido de fazê-lo permanentemente voltado "para si mesmo", confessor e confidente, culpado e culpabilizado, narcísico e confiante na promessa de tornar-se tão mais "autêntico" quanto mais "esvaziado" for da própria intimidade. A vontade de saber ocidental, tão bem descrita por Foucault, tem na mídia uma visibilidade considerável. Assim, por exemplo, a vontade de saber sobre a mulher, sobre a criança, sobre os homossexuais, sobre os jovens vai se tornando cada vez mais evidente. Há que se cercar esses "sujeitos infames", que teimam, que ousam aventurarse por onde menos se espera.

Antes de trazermos alguns dados para análise, sobre como os jovens com quem interagimos fazem referência à sua relação com a mídia e às "verdades" de nosso tempo, veiculadas acentuadamente nesses espaços, cabe aqui um parênteses, para explicitar algumas características da pesquisa a que nos referimos. Durante três anos (2004-2006), o grupo de investigação se ocupou em levantar e analisar produtos veiculados nos meios de comunicação, sobretudo na TV de canal aberto no Brasil, e que se mostravam visivelmente destinados ao público de 15 a 24 anos (ou que a esse grupo faziam clara alusão, como no caso de reportagens especiais sobre juventude e seus "problemas"). Ao mesmo tempo, fizemos uma seleção, dentre esses produtos, de alguns que tratassem explicitamente de questões sobre formas de vida jovem, envolvendo trocas entre grupos, relações com os "diferentes", práticas políticas contemporâneas, e assim por diante. Alguns trechos de programas foram editados e apresentados a grupos de recepção (estudantes de Ensino Médio e universitários), como ponto de partida para debates, gravados em vídeo.

Ao analisar programas de TV e ao estudar o texto produzido nos encontros com os estudantes, a respeito daqueles mesmos produtos, observamos que estudantes de Ensino Médio e universitário tiveram oportunidade de, falando a partir da mídia e sobre ela, falar de si mesmos, expor contradições e conflitos, produzir pensamento sobre os riscos e perigos de nosso tempo, sobre as mudanças que se operam em suas vidas, no que diz respeito a sexualidade, corpo, intimidade, política, cidadania, diferenças, preconceitos, vergonhas, medos, ação da própria mídia, questões de classe social, gerações, etnia, gênero. Seus depoimentos, como veremos a seguir, giraram em torno de alguns sintomas básicos de nossa cultura - como a transformação radical das esferas pública e privada, a colocação do corpo, da sexualidade e da intimidade como centro das atenções [produzindo aquilo que o psicanalista Jurandir Freire Costa (2004) chama de "subjetividade exterior"], o declínio do amor ao público e a imediata solidariedade com o que é da ordem do privado, a estetização do cotidiano, entre outros.

Assim, foi possível observar, entre grupos jovens, o quanto estes são interpelados por discursos dominantes, referentes a um excessivo narcisismo, centrado especialmente em "verdades" que circulam nos diferentes espaços sociais, de modo particular nos materiais midiáticos. Tais verdades dizem respeito a uma espécie de convite que as diferentes mídias parecem fazer, incessantemente, de que cada um de nós se volte para si mesmo, para seu corpo, para suas preocupações mínimas e cotidianas, bem mais do que para qualquer outra questão mais 
ampla, do ponto de vista político e social. Diferente do que descreve Foucault (2004) a respeito da experiência clássica grega e romana, o reforço de si mesmo e da própria singularidade agora não se faz fundamentalmente no espaço público e em nome de uma ação na polis. Hoje, ao que parece, a sugestão de um tipo de aperfeiçoamento de si mesmo se daria quase sempre em função da afirmação da sexualidade, do corpo belo e jovem, da confissão da intimidade, da experimentação de um falar incessante, confundido com autenticidade, como tão bem escreveu o psicanalista Jurandir Freire Costa (1999). Ser uma pessoa autêntica, segundo Costa, significa hoje "dizer tudo", não medir palavras, confessar tudo sobre si mesmo e inclusive sobre o outro. Do ponto de vista ético, parece que a invasão do espaço do "outro" torna-se algo sem limites. Nos depoimentos dos jovens pesquisados, como veremos adiante, esse modo de ser de nossos tempos fica muito evidente.

Todas essas questões, sobre exposição pública da sexualidade, dos corpos e da intimidade, portanto, ganham força num outro tipo de espaço público, bem distinto daquele de que nos fala Foucault, quando se refere aos gregos clássicos e romanos. Refiro-me ao espaço da mídia, em que a referência aos cuidados consigo mesmo e com os outros ganha contornos bastante específicos e, parece-me, fortemente marcados não por um convite à ação na polis, mas por um investimento narcísico constante, que inclui o julgamento permanente do outro. Poderíamos dizer que nos produtos da mídia contemporânea haveria um foco recorrente: na mesma medida da exposição de si, faz-se um julgamento e uma nomeação do outro. No caso, interessa-me a nomeação do "outro jovem", pela mídia e pelos próprios meninos e meninas estudados. O que conduziu boa parte da análise dos dados foi justamente pensar como neles percebemos configurações de um tipo de "normalidade jovem", proposta na cultura, de modos de subjetivação nos quais se faz o aprendizado do que seria espaço público, vida privada, ação política, e assim por diante, como veremos nos exemplos que analisamos nos próximos tópicos do texto. Apoiada em Foucault, entendo que todo esse aprendizado não ocorre verticalmente nem sem formas, mesmo que silenciosas, de resistência: o trabalho com os grupos de recepção acabou por mostrar, em diferentes momentos, o quanto a própria ação sobre os produtos da mídia, os debates, o pensamento a respeito dos temas tratados nos programas de TV permitiram colocar-nos diante de algumas proposições que, nitidamente, apareciam como surpresa, como indagação, enfim, como possibilidade de "pensar de outro modo" a vida de homens e mulheres de 15, 20 ou 25 anos, neste País.

\section{TV: uma verdadeira "mãe cultural"}

Em primeiro lugar, é importante ressaltar que, no Brasil, para os mais diferentes grupos sociais, a televisão é parte indiscutível do cotidiano: ela existe como necessidade, presença, lazer e companhia, como se operasse como uma grande mãe cultural, plenamente acolhedora. No caso dos jovens, desde o início dos anos 90 temos uma verdadeira explosão de produtos destinados prioritariamente a eles na televisão brasileira (muitos dos quais importados dos Estados Unidos, como é o caso do seriado Friends, conhecido em vários pontos do mundo - só para citar um exemplo). O fato é que a TV parece dizer a esses jovens: Venha para mim, eu estou aqui para acolher você, para falar de você e com você, sobre sua vida, seus problemas, sua possibilidade de ser feliz:

Essa mãe cultural, como vários estudantes expressaram em seus depoimentos (especialmente nas escolas públicas), existe não só como lazer e distração: existe para ocupar um importante lugar de "proteção", na medida em que, nas camadas populares, o espaço público da rua é percebido (e sentido, literalmente, na carne) como lugar de perigo, numa sociedade que ainda carece de espaços para crianças, adolescentes e jovens, para além do tempo na escola. Vejamos alguns exemplos. "Não tem nada pra fazer" - afirma um dos estudantes de uma escola estadual, do centro de Porto Alegre. O mesmo aluno, de 16 anos, sintetiza o drama de muitos deles: "Melhor ficar em casa vendo novela do que na rua, não tem o que fazer. [Em vez de] fazer na rua o que não deve": "cheirar, fumar, se prostituir". Outro colega acrescenta: "Na rua é 
perdição". Essa oposição entre mundo da rua e mundo da televisão parece indicar uma precariedade da nossa vida pública, fato que nos conduziria "naturalmente" à televisão - um lugar que, além de tudo, nos é mostrado como democrático, igualitarista, nivelador, como escreve a crítica argentina Beatriz Sarlo (1997b). Em outras palavras: os estudantes que entrevistamos mostram o quanto a vida urbana (no caso de Porto Alegre e de inúmeros centros urbanos do Brasil) ainda é precária, em termos de acolhimento dos diferentes grupos, pela pouca oferta de espaços públicos, gratuitos, de lazer, de trocas culturais; ao mesmo tempo, esse fato é agravado pelas mudanças graves vividas nas grandes capitais brasileiras, de proliferação de situações de violência, que atingem de modo bastante forte os jovens. Pesquisas recentes mostram, por exemplo, que a violência tem sido uma das causas mais graves de mortes entre jovens de 15 a 24 anos, especialmente os jovens do sexo masculino ${ }^{4}$. Os jornais impressos, as revistas, telejornais e os programas de reportagens, nas grandes redes de jornalismo no Brasil, por sua vez, garantem espaços privilegiados a esse tipo de notícia que, mesmo tendo fundamento em fatos reais, aparecem com mais freqüência, já que garantem audiência certa entre os diferentes públicos. Beatriz Sarlo refere-se a esse contraste, que foi claramente expresso por nossos jovens em seus depoimentos: as ruas da cidade são violentas, mas há um lugar acolhedor, a TV, aberto a todos, sem distinção, em que todos são recebidos, seja como objeto dos programas e reportagens, seja como alvo, em termos de endereçamento.

Para os jovens pesquisados, a TV oferece múltiplas formas de identificação. Cada um encontra nos diferentes produtos televisivos alguma possibilidade de afirmar: "Eu estou ali", "aquilo me toca", "eu sou bem parecido com aquela pessoa". Um programa como Big Brother é exemplar no sentido de oferecer tais possibilidades: os alunos de Educação de Jovens e Adultos, de nossa pesquisa, a maioria de camadas populares, mostraram identificar-se com uma das participantes de uma edição do $B B B$, professora do sertão nordestino, mesmo duvidando que ela "caminhava 36 quilômetros por dia" para chegar à sua escola. O importante para eles é que ela era professora, "incentivava as pessoas que não querem estudar, incentivava o povo a estudar, era essa a idéia que passava pra gente", como afirmou um dos alunos ${ }^{5}$; como esse, muitos outros exemplos poderiam ser trazidos, de oferta de identificação no espaço da TV.

Numa escolas públicas, por sua vez, os alunos também expressaram que vêem na programação da TV brasileira fonte direta de identificação com os adolescentes: "Eu acho interessante que eles falam sobre drogas, sobre preconceito, sobre duas pessoas que gostam do mesmo sexo", diz uma das meninas. Mesmo que considerem a TV (no caso, o programa Malhação) "fora da realidade", "a gente não tá ali" a turma diz que naquele lugar "tem gente da nossa idade". Uma das alunas explicita: "O que eu acho legal da Malhação é que mostra que adolescente também tem um certo tipo de problema, passa por dificuldades, que a maioria dos adultos acha que é besteira, mas que [é coisa] que a gente passa também". Outra colega, referindo-se à Novela das Oito, diz que "Mulheres Apaixonadas" igualmente "trata de vários problemas. E [...] não é tão fora da realidade quanto a Malhação".

Importante ressaltar que a pesquisa que fizemos está em sintonia com outras investigações, como a do Instituto de Cidadania, "Perfil da juventude brasileira", de 2003, que aponta entre outros dados os desejos não realizados de jovens brasileiros de 15 a 24 anos, quanto a lazer e entretenimento (Abramo, 2005: 54). No caso dos grupos de escolas públicas que entrevistamos, o que os tira da TV é a própria escola e também algumas "comunidades", de pagode, de dança, do CTG (Centro de Tradições Gaúchas), assim como atividades esportivas,

${ }^{4}$ Segundo dados do IBGE, divulgados em 2007, os percentuais relativos à morte por homicídio, entre jovens de 20 a 29 anos, quase duplicaram nos últimos 25 anos (ZERO HORA, "Violência deixa homens para trás na longevidade", 04/12/2007, p. 36-37).

${ }_{5}^{5}$ Como aparece na pesquisa Projeto Juventude, efetivamente o assunto que mais interessa aos jovens é exatamente a educação (ao lado do emprego e do trabalho), bem diferente do que normalmente se diz que interessa a esses meninos e meninas - sexo e consumo de drogas, por exemplo. 
especialmente jogo de futebol. Mesmo considerando estudantes de nível universitário e alunos de escolas particulares, pode-se dizer que para a maioria deles existe, concretamente, a dificuldade financeira de freqüentar cinema e teatro, o que acaba por conferir à TV um papel maior ainda no que se refere às opções de lazer ${ }^{6}$ e de contato com narrativas de ficção: assistir a filmes na televisão parece ser uma prática das mais efetivas entre os estudantes de todos os grupos de recepção, confirmando dados de pesquisas de mais de 20 anos, que mostram o quanto os públicos infantil, adolescente, juvenil (e adulto também) buscam na TV principalmente um modo de interagir com a ficção, a narrativa, o drama. Certamente, abre-se aí um espaço importantíssimo, ainda pouco explorado nas escolas, de acolher adolescentes e jovens para as diferentes formas de expressão, em que as narrativas ficcionais predominem, como forma de trabalhar sobre si mesmo, na mesma medida em que existiria uma interação com o outro, uma experiência de criação coletiva, voltada para o político - no sentido mais amplo dessa palavra.

É preciso reconhecer, também, que a grande "mãe cultural", quando posta em debate, como sucedeu nos grupos de recepção, é vista não apenas como aquele lugar que acolhe: em todos os grupos estudados, ela apareceu também como objeto de crítica. Programas destinados a jovens (entrevistas, talk shows, telenovelas, seriados), ou que os colocam como tema principal (as repetidas reportagens sobre como tratar dos "problemas" da juventude, em todos os canais de TV) - todos esses produtos foram questionados pelos seis grupos da pesquisa, especialmente porque "não trazem a realidade da gente".

Debater os modos pelos quais a TV faz parte da vida dos jovens acaba por abrir espaço não só para outras formas e meios de comunicação (cinema, Internet), como especificamente para pensar mais profundamente a própria televisão: os jovens oscilam entre o reconhecimento de que programas como Malhação, por exemplo, atraem porque "mostram a sociedade", e ao mesmo tempo provocam alguma rejeição, na medida em que lá é o reino da artificialidade e da mesmice. "A história é sempre a mesma", mesmo que se trate de um tema polêmico, diz um dos alunos da escola particular. E os temas também se repetem, as próprias polêmicas são sempre as mesmas: "tipo, o amor proibido, não sei o quê, [...] eles nunca podem ficar juntos" ou "o cara é gay": "é sempre igual, aí começa a enjoar". Ou seja, tanto esse modo de construir uma narrativa de ficção, em torno de temas que se repetem, mereceu a crítica dos estudantes, como o fato de na TV um modo de acontecer a repetição é também o recurso a classificar, a apontar tipos de pessoas ou de modos de ser, desejáveis na sociedade, como referiram alguns alunos do Santa Rosa.

Em outras palavras: o debate permitiu abrir espaços para algo mais, além da adesão pura e simples dos jovens à mídia televisiva e a seus imaginários. Mesmo que muitos deles tenham replicado a afirmação já constante do senso comum, de que "a TV manipula", "faz as cabeças", o fato é que cada detalhe analisado, dos produtos a eles mostrados, em sessões de mais de duas horas em cada encontro, produziu um distanciamento dos meninos e meninas em relação à sua experiência cotidiana com a televisão. Tal distanciamento, a meu ver, produziu nos grupos um questionamento a respeito do mundo em que vivem, colocando - pesquisadores e pesquisados numa espécie de teia de relações, em que acabamos nos vendo como alguém que pensa o seu tempo e suas experiências. A seguir, veremos exemplos desse exercício da crítica, permitido pelo debate. 


\section{A obsessão pelo ato classificatório}

Dentre as críticas mais fortes manifestadas por todos os grupos de recepção está a de que os programas de TV não cessam de "classificar" o outro jovem. Haveria uma constante exposição não só dos tipos de pessoas ou de modos de ser desejáveis na sociedade, mas também daqueles que "deveriam" de alguma forma ser excluídos. Com o avanço das novas tecnologias e do acesso a tantas imagens e a tanta informação, talvez tenhamos chegado a um momento extremo no processo de individuação e classificação dos sujeitos, para a intensificação do controle sobre a sociedade - processo do qual nos fala Foucault em sua obra, sobretudo em Vigiar e punir (1991) e no curso Os anormais (2001). Todas as diferenças podem ser mostradas, mas há que reuni-las em blocos, há que nomeá-las e dizer o que há nelas de conveniente, correto, certo; também o que há nelas de problemático, a rejeitar, a afastar para bem longe.

Entre as estudantes universitárias ${ }^{7}$, examinar programas como o Big Brother Brasil permitiu que elas expressassem detalhes de como percebem as estratégias de captura dos diferentes públicos: as alunas entendem que os telespectadores, especialmente os jovens, tornam-se alvo de uma curiosidade criada, uma "curiosidade de saber" - ou uma "vontade de saber", como diria Foucault (1990); há também o apelo ao envolvimento com figuras-tipo (a professora nordestina pobre, o rapaz "malhado", a "miss", a babá, o homem gay, e assim por diante), que de alguma forma tocam as pessoas, pelo que representam como figuras masculinas ou femininas, como homens e mulheres de uma determinada classe social, profissão, idade, com um certo tipo de padrão corporal, um certo "jeito de ser da pessoa". Cada um delineia-se como um show à parte, alguém a ser desejado, em virtude, principalmente, de sua performance midiática.

Estamos efetivamente no centro do que Guy Debord (2002) chamou de "a sociedade do espetáculo". É disso que falam essas alunas, quando lembram o fato de o apresentador do Big Brother tratar os participantes do programa como "heróis". Essa observação levou-as a pensar sobre a TV como um espaço que se oferece como lugar da perfeição, em que desfilam pessoas e objetos inalcançáveis, em comparação com as vidas simples dos "pobres mortais". Segundo as estudantes universitárias, a TV nos mostra que não estamos bem com o que temos e somos; precisamos sempre buscar outras metas, semelhantes àquelas dos "heróis" da TV: parece que a nossa vida nunca tá perfeita, porque eles são os perfeitos [...]. Isso gera uma insatisfação, porque daí não se fica satisfeito com o próprio corpo, porque o corpo que se vê na TV é o corpo sarado, malhado. [Também] não se fica satisfeito com o próprio trabalho, porque o trabalho dos caras na TV é um trabalho que permite a eles terem tempo de ir pra academia, de cuidarem dos filhos, e eu não tenho nada, e aí tu não tem nenhum pouco daquilo que colocam ali como correto e aí tu quer mais é sair um pouco da tua realidade e entrar naquilo ali”.

Ora, entendo que o recurso a uma estratégia de linguagem como essa - de chamar de "heróis" os participantes de um reality show - é bastante sintomática de uma sociedade que constrói e cristaliza, veicula e reforça determinados modos de socialização, determinados modos de subjetivação, em que qualidades como coragem e heroísmo mostram-se como exclusivas de determinados personagens midiáticos, aos quais se associam o corpo escultural, o sucesso individual, o prêmio em dinheiro, o narcisismo a qualquer preço, como fica evidente em programas como Big Brother Brasil, bem como nos diferentes seriados protagonizados por figuras jovens - os quais são cotidianamente alimentados por reportagens em todo o tipo de revistas, de modo especial aquelas dedicadas a falar de "ricos e famosos", como Caras e tantas outras publicações que se dedicam a falar de atores e personagens da TV.

Hannah Arendt opõe a essa fórmula (do narcisismo a qualquer preço) o necessário aprendizado de um tipo de heroísmo e coragem cuja marca principal seria a de uma disponibilidade para "estar no mundo", para inserir-se nele arcando com todas as conseqüências que essa entrega acarreta: para ela, ser "singular" é agir, agir pela palavra, pelo discurso, sem ter o

\footnotetext{
${ }^{7}$ Refiro-me ao grupo de alunas do Curso de Pedagogia.
} 
foco no prêmio material ou no sucesso narcísico. Coragem e heroísmo teriam a ver, nessa perspectiva, com a convivência plena com o outro, com quem dividimos poder e palavra, com quem somos, nós e ele, singularidade. Como escreve Arendt, falar em pluralidade humana é falar da "paradoxal pluralidade de seres singulares" (Arendt, 2000: 189). Defendo, com a pensadora, que o agir humano está diretamente relacionado à realização do inesperado, pelo discurso, pela fala, pela expressão, que não devem ser confundidos com mera "conversa", ou meio de atingir determinado fim, palavras que "nada revelam" (Arendt, 2000: 193). Antes, trata-se de uma prática política, prenhe de energia, independente de fins ou produtos acabados.

Essas proposições de Arendt tornam-se fundamentais na análise dos dados da investigação feita e parecem-nos perfeitamente atuais e pertinentes para acompanhar a angústia dos jovens com quem debatemos, os quais se defrontam, diariamente, com um tipo de "socialização midiática" - se podemos usar essa expressão -, segundo a qual aprendemos nossa pequenez, nossa mais acabada imperfeição, diante dos belos, ricos e famosos. Os depoimentos mais enfáticos, como o das universitárias que ficaram mais de 30 minutos exemplificando como se sentiam "menores", em suas opções de vida, seus recursos financeiros, seus corpos - se comparadas às figuras midiáticas -, indicam que não se trata de um aprendizado semelhante àquele de filósofos antigos, como Sêneca (estudados por Foucault no célebre curso $A$ hermenêutica do sujeito), segundo o qual o exercício de ver-se como um grão de areia tinha a função de olhar para si e rever o valor dado a gestos, figuras e atos pouco significativos, para selecionar prioridades na arte de aperfeiçoar a si mesmo (Foucault, 2004). Pelo contrário, o sentimento é, por vezes, o da própria anulação de si. Quando a estudante diz que "eles" são sempre os perfeitos - eles, os "heróis" da mídia - mostra-nos como esse trabalho intermitente dos diversos meios de comunicação participa, intensamente, da produção de nossas subjetividades, no sentido da diminuição de si, e que existe, paradoxalmente, com o que já foi referido anteriormente, de elegermos nosso corpo, cada um de nós, como o grande centro de atenções. É como se o mundo da perfeição não nos pertencesse jamais, embora, contraditoriamente, ele seja oferecido como o que deve ser desejado, buscado todos os dias, para sermos aceitos socialmente, de modo especial no que se refere à beleza de nosso corpo e daquilo que vestimos e ostentamos como posse (nosso par de tênis, a griffe da calça jeans ou da camiseta, e assim por diante).

O sentimento manifestado pelas estudantes, de diminuição de si mesmo (o sentimento de que "eu não tenho nada", "eu não sou nada" diante daquilo que está na TV) e de entrega ao que lhes é oferecido como belo e desejável, remete-nos a um problema mais amplo, da produção e da afirmação permanente da desigualdade, e que não é privilégio dos meios de comunicação. $\mathrm{Na}$ análise das diversas formas de relação com o "outro" propostas pela mídia, e comentadas pelos seis grupos de estudantes, começamos a perceber que nossa sociedade, como já nos tinha alertado Foucault (1991), cada vez mais se sofistica em aperfeiçoar mecanismos de divisão entre os sujeitos, de tal forma que, hoje, embora todas as conquistas de lutas e movimentos sociais, num país como o Brasil, ainda assistimos a práticas e discursos que não se cansam de diminuir o outro, de rebaixá-lo, de arrogantemente menosprezá-lo e humilhá-lo, sempre sob novas e sutis formas. No Brasil, a recente discussão sobre as cotas de negros e de estudantes oriundos de escolas públicas, para o ingresso nas universidades públicas, trouxe à tona inúmeras manifestações de como ainda estão vivas várias formas de exclusão do "outro", especialmente o outro negro e pobre.

Jorge Larrosa (2004), no texto "Educação e diminuição", sublinha o papel da educação formal nessa prática cotidiana de elevação de si pelo rebaixamento do outro - e que percebemos estar mais do que nunca presente nos materiais televisivos, que analisamos e discutimos com os jovens de nossa pesquisa. Interessante a destacar é o casamento entre as práticas de pedagogia escolar e as práticas da pedagogia midiática: ambas se irmanam na produção diária da desigualdade, a partir especialmente de um olhar que identifica, classifica e ordena, produz e reproduz corpos, objetiva sujeitos, esforça-se em reduzir diferenças e em aplainar possibilidades de surpresa ou experiências não pensadas. Estudantes de Pedagogia, que durante o curso visitam 
escolas públicas em Porto Alegre, narram freqüentemente vários casos de práticas classificatórias no ambiente escolar, manifestadas tanto por professores como por alunos (crianças e jovens): expressões do senso comum - inteligentes versus "burros"; gordos e magros; bonitos e feios; bem arrumados e "maloqueiros"; bem-comportados e desordeiros; "populares" e "apagados" recebem outros nomes, talvez mais sofisticados, nos documentos oficiais dos órgãos públicos ligados à educação, mas ambas as situações não deixam de pertencer à lógica das práticas classificatórias que nossa sociedade tão bem soube construir, como nos ensina Foucault, especialmente na conhecida obra Vigiar e Punir. O que observamos em nossa pesquisa é que uma das estratégias de linguagem das diferentes mídias, especialmente da TV, parece ser, como nos ensina Beatriz Sarlo, a de buscar uma simplificação, pelo caráter de imediatez, da comunicação direta, aquela comunicação sem necessidade de maiores mediações e complexidades - o que, a meu ver, significaria por exemplo fugir às simplificações que classificam grupos e pessoas de modo simplista --, como veremos adiante. Para Sarlo (1997a), essa opção de linguagem não deixa de ser um modo político de comunicar, de informar e de narrar.

\section{Diferenças e (a)normalidades na mídia jovem}

Carlos Skliar, no livro Pedagogia (improvável) da diferença: $e$ se o outro não estivesse aí?, ao invés de oferecer um "catálogo da alteridade", uma listagem literal dos outros (a capturar), insiste em perguntar sobre a "espacialidade do outro", ou seja, sobre "a distribuição do outro no espaço da mesmidade e num espaço outro" (Skliar, 2003: 103). O autor nos fala de uma espacialidade colonial (o outro visto a partir de um aparato de poder, segundo o qual há que reconhecer diferenças de raça, de cultura, de história, para fazer delas objeto exótico e estereotipado ou mesmo para repudiá-las, vitimá-las, culpabilizá-las); em seguida, refere a espacialidade multicultural (no limite, o outro apenas tolerado, oficialmente reconhecido, o outro da "relação pluralizada, generalizada e de certo modo obrigatória entre nós/eles"); finalmente, a(s) espacialidade(s) da(s) diferença(s) - "o outro irredutível, a distância do outro, seu mistério e, ao mesmo tempo, o espaço da mesmidade como sendo refém do outro" (idem, p. 104).

Para efeito da pesquisa aqui discutida, o conceito de alteridade torna-se fundamental, na medida em que, ao discutir com os seis grupos de recepção e ao analisar os produtos televisivos a eles destinados, procuramos justamente descrever e analisar como nossa sociedade tem distribuído espacialmente esse "outro" jovem e como eles mesmos, na condição de homens e mulheres em seus 15-25 anos, se nomeiam e avaliam as formas de sua nomeação naquilo que a indústria cultural destes últimos anos tem construído, veiculado, valorizado. Nossas perguntas, a partir de Skliar, caminham por essas várias espacialidades: estaria a mídia narrando o jovem como um outro colonizado, tornado objeto exótico de desejo, de curiosidade? Os programas televisivos sobre sexualidade adolescente poderiam ser pensados por tal tipo de espacialização da juventude? Ainda: os jovens "diferentes", cada vez mais contemplados na mídia e na publicidade, estariam sendo acolhidos como "diversidade multicultural" ou na sua condição de diferença

\footnotetext{
${ }^{8}$ Entendo que Skliar se aproxima muito do conceito de "différance", de Jacques Derrida. Para o pensador francês, a "différance" não é a mesma coisa que as diferenças. A différance tem uma potência de universalização, não é essência, não é oposição, "mas um movimento de espaçamento, um 'devir-espaço' do tempo, um 'devir-tempo' do espaço, uma referência à alteridade, a uma heterogeneidade que não é primordialmente oposicional" (Derrida \& Roudinesco, 2004: 34). Derrida insiste, no seu diálogo com Elizabeth Roudinesco, que a "différance" não é oposição, muito menos oposição dialética: "é uma reafirmação do mesmo, uma economia do mesmo em sua relação com o outro, sem que seja necessário, para que ela exista, congelá-la, ou fixá-la numa distinção ou num sistema de oposições duais" (idem). Em suma, a "différance", em Derrida, seria "portadora de negatividade, mas também de uma alteridade que escaparia incessantemente ao mesmo e ao idêntico" (idem, p. 33).
} 
mesmo, como outros irredutíveis, completo mistério, "différance"? Vejamos a seguir alguns depoimentos sobre os diferentes, na pesquisa feita.

Talvez uma das temáticas mais presentes em todos os 23 debates realizados com os seis grupos tenha sido aquela que se refere à pergunta que atormenta grande parte dos jovens: eu sou normal? Nos encontros, a discussão partia ora do exame de um filme como Matrix ${ }^{9}$, ora dos comentários sobre Big Brother Brasil ou sobre uma reportagem do Jornal Nacional a respeito de tribos adolescentes no Brasil. Eles manifestaram perceber a força do social, da família, da escola e de outras instituições, na constituição dos modos de ser desejados e desejáveis, considerados normais. Como diz uma das alunas da escola particular,

O problema é que se tu não é determinado tipo de pessoa que querem que tu seja, sabe, tu é considerada maluca, louca, sabe?! Tu não é considerada a normalzinha da sociedade. Então tu tem um padrão desde pequena". Eles percebem que não vem somente do mundo adulto a cobrança de uma normalidade: os colegas também excluem aquele que não se enquadra nos padrões do pequeno grupo. $\mathrm{E}$ as exclusões passam por particularidades como a roupa que alguém veste, uma "calça inútil", que "não é de marca. A apresentação do vídeo com uma reportagem sobre jovens no Brasil ${ }^{10}$ foi motivo para os alunos da escola particular exporem uma quantidade interminável de classificações e subclassificações que ocorrem no cotidiano dos jovens: um "nerd", por exemplo, é o "idiota" (como exemplo, citam Bill Gates e todos os hackers, os estudiosos, entre outros "retardados"). Uma "paty" poderá ser "paty de roupa" e "paty de cabeça"; existem mulheres "galinhas" e homens "boyzinhos", homens pegadores, mulheres putas, vagabundas. O debate chega a detalhes inimagináveis: uma roupa da moda só será realmente bem avaliada se o modelo e o tamanho forem exatamente aqueles considerados desejáveis: como admitir alguém que compra uma camisa "três números menor que o [tamanho] dele?"... . Nesse momento do debate, cresce no grupo a exposição inflamada de um sem-número de regras de consumo, de apresentação pública, de como se vestir para ser aceito num certo grupo, num certo tempo específico - regras "naturalmente" aceitas e em nada parecendo compatíveis com toda a crítica feita à mídia, às instituições, a tudo e a todos que constrangem os mais novos a serem deste e não daquele modo. As regras parecem ser propriamente deles, incorporadas como indiscutíveis.

O tema da classificação do outro (e de sua conseqüente exclusão) mobilizou todos os grupos participantes da pesquisa; num dos casos (na escola particular), meninos e meninas demonstraram uma espécie de prazer sádico nessa experiência de negar o diferente - prática possivelmente relacionada com a própria não-aceitação do que cada um rejeita em si mesmo; mas uma prática seguramente violenta e muito de perto relacionada às divisões sociais mais amplas, pelas quais nossa sociedade considera alguns como cidadãos, outros como subcidadãos, como refere o sociólogo Jessé de Souza em seu livro A construção social da subcidadania (2003).

Torna-se difícil para os jovens perceberem o quanto eles mesmos estão submetidos às próprias classificações que praticam no cotidiano. Perguntados sobre isso, respondem que julgam o outro porque ele foge ao padrão, à normalidade. Muitas vezes, buscam justificativas para esse gesto: "Eu acho que não tem uma explicação por que o ser humano tem necessidade de classificar os outros, [talvez seja para] organizar melhor o mundo que está em volta dele". Uma menina complementa o colega: "Eu acho que de repente [...] tu te sente frágil em algum ponto e tu vai falar do outro, te defende..." . Uma das alunas do primeiro semestre de Comunicação é enfática e vai direto ao ponto: para ela, os modos como aprendemos a construir nossa identidade

${ }_{9}^{9}$ Filme realizado por Andy Wachowski e Larry Wachowski (EUA), em 1999. Seguiram-se Matrix Reloaded e Matrix Revolutions (ambos de 2003). A trilogia de filmes de ficção científica parece fascinar os adolescentes, talvez por tratar da possibilidade de existência de um sistema artificial a manipular a mente das pessoas, e por confundir realidade e ficção, bem como por tocar no grande tema da liberdade.

10 Matéria veiculada no Jornal Nacional - Especial Juventude Urbana, de 19/06/2003, da Rede Globo. Cabe lembrar que o Jornal Nacional, junto com a Novela das Oito, é o mais destacado programa da televisão brasileira, em termos de audiência (média de 60\% de audiência, de segunda-feira e sábado). 
passam necessariamente pelo julgamento e pela classificação e diminuição do outro: [Aprendo que] "pra eu me sentir bem, eu tenho que saber que as pessoas que estão à minha volta têm defeitos também". Ora, é justamente essa a discussão que faz Jorge Larrosa (2004), quando escreve que a codificação do outro está relacionada à busca de tornar compreensível algo que, talvez, seja da ordem do inapreensível, do imprevisível, do provisório; mas se trata de uma busca em que as pessoas acabam por comprazer-se no exercício da codificação, a partir da nomeação de si mesmo como normalidade, como sujeito-bem-situado, no interior de um processo de construção vertical do outro, como alguém deslocado, insubmisso, alguém que deveria ser outra coisa, não o que é.

Olhar "de cima", como escreve Larrosa (2004: 277), é olhar com distância; é olhar a partir do que falta no outro. Essa seria uma das características básicas do discurso pedagógico escolar, se o pensarmos como relacionado a um espaço institucional disciplinar, na perspectiva foucaultiana, também defendida por Larrosa. Aliás, a competência a ser adquirida para fazer parte desse lugar institucional e de saber - a escola e o pensamento pedagógico - seria justamente aprender a perceber e a identificar a falha, o buraco, o que está incompleto, e então, a partir daí, empreender projetos de completude, de reforma e melhorias. A grande maioria dos produtos midiáticos que temos estudado ${ }^{11}$, em especial aqueles destinados aos públicos infantil e juvenil, parecem não fugir a essa mesma proposta; parece que não vivem sem, obstinadamente, apontar as insuportáveis falhas das meninas que estão gordas demais, dos meninos que se drogam demais, das jovens que engravidaram cedo demais. Tudo é "demais", tudo seria demasiado diferente, e é preciso corrigir tanta falha, tanta falta de normalidade.

Penso que um dos paradoxos, na modernidade, e que vemos tão presente nos produtos midiáticos - nesse afã de classificar, julgar, separar e chamar à normalidade -, seria o de que justamente nesse lugar se faz uma interpelação a partir de indivíduos que se destacam, de alguém que se faz herói, fenômeno ou celebridade, de alguém que consegue distanciar-se das pessoas comuns. Portanto, parte-se de alguém quase fora do "normal", justamente para chamar à normalidade, para criticar o desvio da norma. Num dos encontros com calouros do Curso de Comunicação, o debate sobre os "outros" levou o grupo a discutir diretamente o tema da diminuição do outro: o gordo, o que tem espinha no rosto, o que foi ou é repetente, os chamados "burros" e fracassados, os magrelas, os gays, as lésbicas, etc. Conforme eles disseram, qualquer fato, qualquer dado, qualquer marca do corpo poderá ser motivo para "pisarem no pé do outro", para "carimbarem" o sujeito. Ser gordo, ser homossexual, ter o cabelo crespo, vestirse fora da moda - tudo é motivo para buscar rapidamente um apelido, um nome classificador e especialmente para separar esses "outros" que se tornam indesejáveis.

Haveria um misto de divertimento sádico e de sofrimento diante de tantas classificações, de tanto horror ao diferente, quase sempre colocado numa "espacialidade colonial", como diz Skliar, em que o diferente ou é transformado em vítima, é culpabilizado ou terminantemente repudiado. No máximo, o que os jovens dos grupos de recepção conseguiram foi avançar no sentido de expor a experiência de uma certa tolerância com o outro. A dualidade permanece, nas narrativas da mídia, nos depoimentos dos estudantes. Em ambas as fontes de enunciação, observa-se a centralidade do corpo e do "visual", na base dos julgamentos classificatórios. O cotidiano desses jovens é narrado como permanentemente ocupado com tamanhos de peitos e pernas, gorduras em excesso, barrigas, modos corporais de gays ou lésbicas, "monstruosidades" que não cessam de expor-se ao crivo de quem aprende, desde a infância, a olhar com desconfiança para aquele que "não sou eu".

"Acho que tu tem que ser normal. Tem um negócio [sobre isso, sobre a normalidade] que é mais forte que a gente" - diz uma das universitárias, de classe média, do Curso de Comunicação. Os vários depoimentos sobre as diferenças marcadas nos corpos, quase sempre faladas como indesejáveis, e a reflexão de que não haveria forma de livrar-se dessa quase

\footnotetext{
${ }^{11}$ Ver Fischer, 2001; 2005b.
} 
compulsão a classificar e a rejeitar o diferente, nos remetem ao belíssimo curso de Foucault, $O s$ anormais $^{12}$, em que aprendemos o quanto nossos modos de classificar o outro e principalmente de julgar o que seria normal e anormal dependem de uma operação complexa e ampla, na qual estão envolvidas inúmeras instituições e práticas. Não há como deixar de relacionar as classificações dos jovens da pesquisa com os relatos trazidos por Foucault em seu curso, sobre a rejeição e exclusão dos leprosos, dos pesteados, dos loucos, das prostitutas, dos monstruosos. O aprendizado da classificação é o aprendizado da individualização, da divisão e da subdivisão do poder, "que chega a atingir o grão fino da individualidade" (Foucault, 2001: 57). Numa das escolas particulares, os alunos chegaram ao refinamento de contar a trajetória de uma menina que sofreu sucessivas exclusões: primeiro por ter o cabelo crespo (era então chamada de "repolhuda", sua cabeça era comparada a um repolho) e, depois, "piolhuda" (deveria ter piolhos, já que raspou a cabeça, movida pelo mal-estar de seus cabelos crespos); finalmente, ela aderiu a todos os ditames de uma vida "normal", alisou os cabelos e vestiu as roupas de griffe - mas nem isso a salvou da classificação: passou a ser chamada de "patricinha".

Ora, relacionar excluídos como os pesteados do século XVIII na Europa com os obesos, mal vestidos, gordos ou homossexuais do século XXI no Brasil não significa dizer que todos esses rejeitados se equivalem. Trata-se, ao contrário, de mapear os modos de existência classificatórios de nosso tempo, levando em conta sobretudo que nossa sociedade é hoje pautada por algo que se poderia chamar, com Debord, de moral do espetáculo - no caso, do espetáculo midiático. Também é preciso situar concretamente como, em nosso País, se operacionaliza essa moral, de modo a ordenar e reordenar nossas vidas, a partir de um sem-número de classificações, num complexo desfile de imagens de desejáveis e de indesejáveis. Tanto Foucault como Debord, portanto, nos ajudam a situar, a pensar essas práticas classificatórias no nosso tempo e lugar, para que possamos ir adiante e produzir novas indagações, no caso, sobre a condição juvenil brasileira.

\section{Ricos e pobres: a diferença radical}

De acordo com Zizek (2003), vivemos um tempo em que grandes e sérios conflitos econômicos e políticos passam a ser deslocados para o terreno da cultura: sim, as diferenças são inúmeras, há ricos e pobres, mas o interesse é centrado no chamado reconhecimento das diferenças culturais. "Por razões filosóficas - diz Zizek -, não acredito que o reconhecimento das diferenças seja o último horizonte da política. Para reconhecer você como diferente, nós devemos partilhar um campo mínimo de solidariedade. Sem isso, a diferença não é interessante para o pensamento. A diferença não vem primeiro". Para o filósofo, a obsessão pelo assédio sexual, por exemplo, na nossa cultura, e todas as conseqüências disso num país como os Estados Unidos, "só demonstra que, no nosso contexto ocidental, tolerância significa: 'Vamos tolerar o outro desde que ele fique a uma distância segura'. O que não quer dizer outra coisa além de: 'Eu realmente não tolero sua proximidade, não chegue muito perto de mim'. Tolerância, no multiculturalismo, é apenas outro nome da intolerância" (Zizek, 2003: 6).

Ou seja, esse pensador não desvincula o debate teórico, a respeito das diferenças, de uma atitude e de um agir políticos: para ele, as políticas contemporâneas de identidades tendem a defender identidades particulares, e não identidades coletivas; valorizam uma política das multiplicidades. E argumenta: uma agência econômica como o Fundo Monetário Internacional toma decisões-chave no mundo de hoje, embora não esteja submetida a nenhuma regra de controle democrático. Para nós, essa discussão é básica, uma vez que nossas iniciativas e lutas, em nome das mulheres, jovens, negros, homossexuais, inserem-se por dentro da dinâmica do capitalismo global (Zizek, 2003: 6-7). Temos aí um problema complexo a ser pensado, já que,

12 Curso proferido em 1975 no Collège de France, em Paris. 
nessa dinâmica, ocorre que o mercado e a publicidade rapidamente absorvem nossas lutas e as transformam em produtos consumíveis. Ficou famosa no Brasil a série de comerciais da Fiat, com o bordão "Está na hora de rever os seus conceitos", em que negros e homossexuais, por exemplo, aparecem em situações de discriminação, as quais são criticadas na campanha. Obviamente, a Fiat no Brasil estava buscando uma revitalização de sua imagem, bem como desejava atingir novos alvos, novos consumidores. Mas o fato é que de certa forma expôs lutas reais e fundamentais de nossa sociedade, mesmo que absorvendo-as e transformando-as em objeto de consumo.

Pois bem. Na pesquisa aqui discutida, os jovens com quem interagimos também debateram sobre um "outro" que, do ponto de vista social mais amplo, nos intimida, pois é um outro que não se cansa de aparecer como aquele que sinaliza a grande diferença, numa sociedade como a brasileira. Esse "outro" pobre, negro, mal-vestido, com fome, bate à nossa porta, faz piruetas na esquina do semáforo, fica diante das vitrines do shopping com seu boné e seu olhar por vezes inquisidor - ele se expõe como parte de uma ampla maioria em nossa sociedade. Já nas micro-realidades também parece proliferar uma quantidade imensa de vários "outros", distribuídos pelas diferentes camadas sociais, e que hoje estariam diretamente vinculados à cultura somática de si mesmo, àquilo que Jurandir Costa (2004) tão bem denomina de "cultura das sensações" ou de "subjetividade exterior". Esses dois grupos de "outros" habitam tanto os programas de TV por nós analisados, como os debates que essas produções instigaram entre os jovens das turmas de recepção, nos grupos em que realizamos a pesquisa.

Numa das escolas públicas, por exemplo, a discussão sobre as classificações mostrou-se fortemente relacionada à posição social, à disponibilidade financeira das pessoas. Embora alguns referissem que ter ou não ter posses é algo que não interessa ("Quem tem, tem, quem não tem não vai ser excluído porque não tem dinheiro" - como diz uma das alunas), vários estudantes afirmaram que os grupos muitas vezes se constituem a partir dos que têm ou não têm "grana". Um dos alunos forneceu o exemplo mais curioso, mas totalmente típico de nossa época: contou que foi julgado pelos colegas porque o tênis dele era "de camelô", não era "de verdade". Nesse grupo, a discussão encaminhou-se para a necessidade de trabalhar, de ter o próprio dinheiro ${ }^{13}$, diferente da situação apresentada por reportagens da Rede Globo (e que foram analisadas pelo grupo), de jovens que recebem tudo dos pais, ou de pessoas que, mesmo trabalhando, são capazes de gastar um salário inteiro com uma "calça de marca". De qualquer forma, no debate estava viva a força do externo, da roupa, do tênis, da moda: eles não titubearam em concordar que "a personalidade muda" [a partir de uma] "característica exterior". Muitos manifestaram a quase impossibilidade de "ser alguém" na turma da escola, se estiver vestindo uma roupa de pobre, comprada em barracas de camelô.

Conforme Costa (2004: 185), nossa sociedade estaria promovendo, com o apoio fundamental dos meios de comunicação, personalidades narcisistas, hedonistas, para as quais cuidar de si significaria obter todo tipo de satisfação sensorial, que passa, inevitavelmente, pelo julgamento da aparência física, dos modos de vestir, dos lugares que se freqüenta, das pessoas com quem se anda. Perde-se aí, segundo o autor, uma perspectiva que considere os longos prazos e os objetivos extra-pessoais - indispensáveis se quisermos pensar na formação de cidadãos cujo interesse se volte para as questões públicas e políticas mais amplas, articuladas com as pequenas lutas cotidianas.

Quanto a outros programas de televisão, em que camadas menos favorecidas da sociedade brasileira são mostradas, como ocorreu com a minissérie Cidade dos Homens ${ }^{14}$, parece

13 Também aqui nossa pesquisa corrobora os dados de "Perfil da juventude brasileira", investigação que mostrou o quanto o item "trabalho" aparece para os jovens como algo extremamente positivo, relacionado a independência, crescimento e auto-realização (cf. Abramo, 2005: 53).

14 A minissérie Cidade dos homens, da Rede Globo de Televisão e da produtora 02 Filmes, foi exibida em três temporadas, desde 2002, e gira em torno dos personagens Acerola e Laranjinha, 
que os jovens - no caso, de classe média e de escola particular - vivem um conflito bem claro: sentem-se "constrangidos" com a pobreza, quando colocados diante daqueles que "não têm nada", e acabam por evidenciar tudo o que separa esses dois mundos sociais. Quando têm a oportunidade de conviver com amigos pobres, sentem-se mal, por terem carro, por terem roupas boas para vestir; sentem-se invadindo um outro mundo, sentem medo, e isso é expresso já pelos pais, inconformados com a amizade do filho, a aproximação com esse "outro" social. "Me sinto meio impotente, de não poder fazer nada...", diz um dos alunos. Outros relatam episódios de assaltos, ou de arrastão em dias de jogos de futebol, falam de medo e ao mesmo tempo do "beco sem saída" dos mais pobres, dos que habitam favelas e vilas nas grandes cidades, da opção pela violência, já que "o meio obriga", como disse um dos meninos. E completou: "[Eles] não têm mesmo o que perder".

A discussão encaminhou-se nesse grupo para a diferenciação entre pobreza e miséria, entre pobreza e violência, entre dar ou não esmola aos que pedem e estão na rua. Todos contam experiências de contato com crianças que pedem dinheiro e comida nas ruas de Porto Alegre e, como tantos outros brasileiros, de todas as idades, vivem o conflito de não saberem o que fazer diante de problema tão grave. Meninos e meninas de 16 anos lembram que a realidade mais ampla é que é violenta; é isso que permite, por exemplo, uma criança, em tantos lugares do mundo, inclusive no Brasil, ser levada a matar, a carregar uma enorme arma como ato "normal" de seu cotidiano. Repetem chavões conservadores sobre pobreza no Brasil, como o de que, quando uma pessoa pobre recebe esmola, sempre "quer mais e mais", e o de que "o cara podia tá trabalhando, podia ganhar dinheiro", como diz um dos alunos, imediatamente questionado por outro colega: "Mas oportunidade de trabalhar não é assim...".

Os outros - pobres, marginais, homossexuais, negros - são mencionados e tratados com as ferramentas que essa geração parece ter: uma certa tolerância e, ao mesmo tempo, a perplexidade diante do preconceito que habita cada um deles e o tímido desejo de transformar essa realidade. É o que Skliar entende como "espacialidade multicultural" do outro: um outro a respeitar, a tolerar, desde que permaneça assim, um outro "menor", mesmo que recebido na ordem de uma certa "pluralidade". Mas o que parecer ser predominante é mesmo a percepção colonizada do outro. Os alunos da escola particular afirmam, por exemplo, que nunca foram atendidos por um médico negro ou por um gerente de banco negro. E, se isso acontecesse, assumem que ficariam surpresos: "Pô, um cara negro, que é isso?". Admitem que somente quando não houver mais essa surpresa "tudo vai tá igual". O mesmo menino pergunta: "Tu acha que as pessoas negras têm as mesmas oportunidades que nós? Olha aqui, meu. [...] Não têm. Olha o favelado. Tu acha que aquela pessoa tem oportunidade de ser médico, trabalhar, fazer uma faculdade de direito?". Esse menino, apesar da indignação, acaba o raciocínio, de forma um tanto conformista: "Quanto todo o mundo trabalhar no mesmo plano, quando tudo tiver igual, a gente vai conseguir olhar igual. Agora não dá”. Outro colega completa: “... nunca vai acontecer esse esquema de poder olhar tudo igual".

Poderíamos dizer que os depoimentos, nos seis grupos de recepção, apontam para um fato que não se pode desconsiderar: a percepção, mesmo que não claramente formulada em muitos casos, que esses jovens têm de que os processos classificatórios, em nossa sociedade, contam com a participação permanente dos meios de comunicação, no sentido de estes produzirem alguns efeitos de verdade sobre todos os tipos de "outros". Os modos de mostrar os outros sociais (sejam os que efetivamente estão do outro lado da rua social, sejam todos os outros-diferentes, as tribos mais diversas de jovens) parecem construir-se segundo uma lógica narrativa que privilegia os guetos, as separações, a não-mistura, a identificação de tribo com roupa e consumo, a cristalização de imagens em que jamais se poderiam perceber quaisquer nuances. Uma das alunas do colégio público federal chega a uma conclusão: "A TV ajuda as

moradores de uma favela na Zona Sul do município do Rio de Janeiro. Teve origem no filme Cidade de Deus (2002), com direção de Fernando Meirelles. 
pessoas a serem mais preconceituosas do que já são!’. Outro colega, nessa mesma escola, concorda: [a TV] "passa uma imagem de que essas pessoas [os pobres] são uma ameaça para nós". Uma das estudantes de Pedagogia, por sua vez, parece complementar o raciocínio dos estudantes de Ensino Médio: "Aprendemos que drogas é horrível nas classes populares, que os pobres é que são o problema”. Outra completa: “[O medo dos pobres] é automático!”. Vários deles relatam situações em que decidem atravessar a rua, quando percebem que se aproxima uma pessoa "escura", mal vestida; ou quando alguém "assim" se aproxima para pedir. É como se um grande inimigo chegasse e pudesse matar, roubar, praticar violência.

Da mesma forma que os outros-pobres se transformam em seres indesejáveis e guetizados, alguém para ficar "longe de nós", as diferentes tribos jovens também merecem um tratamento guetizante e estereotipado. No dia da exibição da reportagem do telejornal Hoje, da Rede Globo, os calouros de Comunicação Social comentaram que, para o jovem chegar a saber quem ele é, precisa achar sua "tribo", "porque tu não sabe quem tu é, se tu não pegou umas pessoas assim como tu e que também gostam de ti...", como diz um dos alunos. Segundo esses estudantes, podemos pertencer simultaneamente a várias tribos, e estas parecem estar vinculadas principalmente a gostos e modas musicais, diferentemente do que é mostrado na reportagem da TV, em que a associação entre tribo e consumo parece predominar, reforçando uma prática que ocorre entre os jovens, de passar a pertencer a uma tribo a partir da adoção de um tipo de vestimenta. "O pessoal que é punk mesmo tem razão de não gostar desses punks de butique", assinala um dos estudantes. Outra aluna lembra que as tribos de hoje estão mudando muito rapidamente, por influência direta da mídia, mas acredita que "as primeiras tribos que existiram surgiram por causa das diferenças de pensamento numa sociedade liberal. A gente pode lembrar os hippies, os punks, que surgiram por quê? Porque tinham valores completamente diferentes. Eu acho que na atualidade a gente tá vivendo num período tão individualista que não importa, não tá importando mais o pensamento das pessoas (...). É um estilo de pensar ou é um estilo de vestir? (...) Só o que a sociedade espera de mim, que eu seja uma pessoa, não mais uma na multidão, que eu tenha o meu próprio estilo. Só que qual é o meu estilo? Não seria o meu estilo de pensar, seria o meu estilo de vestir. Eu acho que tem uma banalização dessas tribos".

Os alunos da escola particular, por sua vez, mostraram estar aprendendo que nos reality shows constrói-se uma narrativa propícia a reunir elementos-chave de uma cultura que, cinicamente, afirma: estamos todos num jogo, quem for mais esperto vai ganhar, que "para se dar bem, vai pisar em cima dos outros pra subir", como afirma um dos meninos. Outro aluno complementa, indagado sobre a prática de "detonar", "eliminar", "mandar para o paredão": "Eu acho que [isso] incentiva mais o individualismo, assim, mais do que a sociedade já está individualista". A turma é unânime em afirmar o quanto, na mídia, aprendem que "não é necessário ajudar ninguém, porque ninguém vai te ajudar". Um dos alunos, provocador, rebate: "Se eu entrasse num esquema desse aí $[B B B]$, eu ia entrar pra pisar na cabeça de todo mundo. Entrar num programa desse aí é pra fazer isso!”. Ajudar o outro, segundo o BBB, para alguns desses alunos, seria fazer o papel de "otário".

Os depoimentos corroboram o que diz Maria Rita Kehl: para ela, a grande excitação de programas como os reality shows não seria exatamente a exibição de cenas eróticas ou de revelações picantes. "O que excita o pessoal é o paredão. Conspirações, traições, armadilhas, estratégias descaradas para passar a perna nos companheiros e garantir a própria permanência: este é o tema de BBB" (Kehl, 2004: 171). Conforme atestam os jovens de nossa pesquisa, parece que esse tipo de programação estaria em harmonia com certas verdades de nossa época, segundo as quais o eu narcísico deve ser satisfeito a qualquer preço e rapidamente, já que espaços institucionais públicos de todos os tipos, como a própria escola, não estariam dando conta das demandas simbólicas dos diferentes grupos sociais. Ali, no Big Brother, ou em tantos outros programas, a TV nos diz que está perto de nós, é rápida e transparente, fala a cada um, melhor do que qualquer outro lugar social, oferecendo uma proximidade imaginária que reforça a descrença no fortalecimento de outras instâncias de vida pública e simbólica. 


\section{Novos espaços simbólicos. Percepção de um "outro" irredutível}

A referência entusiástica dos universitários de Comunicação a uma das escolas públicas estaduais mais conhecidas de Porto Alegre ${ }^{15}$, e que aliás também fez parte da pesquisa, parece sinalizar que haveria uma espécie de desejo, o desejo de pertencimento a alguma tribo que, de alguma forma, pudesse remeter à idéia de "fazer alguma coisa junto", de unir-se por alguma causa, de pensar a política para além dos temas já saturados do roubo e da corrupção. Os estudantes fazem referência aos inúmeros casos de corrupção entre políticos brasileiros, casos amplamente divulgados nos jornais e na televisão nos últimos anos, de tal forma que, segundo eles, seria importante pensar em outro tipo de fazer política. O Colégio "Julinho" se transformou historicamente numa grande tribo, a "tribo mais famosa", porque lá permanece uma idéia de "revolução", de movimento esquerdista, como referem os alunos. Os universitários trouxeram com entusiasmo para o centro da discussão uma escola que já completou 100 anos e que se caracterizou historicamente por uma participação política muito atuante e crítica, particularmente nos anos 60 e 70, e da qual a sociedade gaúcha ainda guarda memória.

Entendo que essa lembrança seria emblemática de outros acontecimentos vividos com os grupos de recepção: a adesão e ao mesmo tempo a crítica à TV; a perplexidade, a dúvida e o confronto com as próprias crenças. Afinal, poderiam esses jovens mostrar-se ou mesmo serem abertos à liberdade de escolhas sexuais? Como poderiam pensar de outra forma sua relação com os mais pobres deste País e as análises que fazem das diferentes condições sociais e econômicas dos diferentes grupos? Por que a rua tem sido o que é, lugar de medo e de "perdição", em contraposição ao espaço doméstico da sala de estar ou do quarto de dormir, diante da janela da TV? Como olhar e receber a diferença, os tantos outros que nunca serão idênticos a nada e a ninguém, diferença pura? Perguntas como essas estiveram vivas em todos os debates, acionados pela exibição de trechos de programas de TV e anúncios publicitários.

Eu diria que a análise dos programas de televisão, feita nas escolas, e sob a forma de debate, abre para nós, educadores, um conjunto de outras questões, relativas ao problema maior da dimensão pública da existência. É disso que trata o último curso de Michel Foucault, $A$ hermenêutica do sujeito, mais de uma vez citado neste artigo. O filósofo problematiza nessas aulas um pouco (ou muito) do que somos hoje, ou do que seria em nosso tempo a possibilidade de lutarmos por uma "ética dos cuidados de si", diferente da ética narcísica e individualista da moral do espetáculo. É bem verdade que Michel Foucault nos descreveu o que foi, para os gregos e romanos clássicos, toda a produção de uma tecnologia de si mesmo, voltada para o aperfeiçoamento de si e em prol de uma ação política, de uma atuação na polis. De qualquer forma, entendo que, embora todos os esforços de nossa cultura, em direção ao apagamento do sujeito da ação política, como refere Maria Rita Kehl (2004), haveria uma demanda, expressa em várias passagens dos depoimentos dos jovens, a respeito da expressão de si, para além da performance narcisista que nos é hoje tão familiar. Penso que o exemplo maior disso foram as discussões sobre escolas que, em Porto Alegre, se tornaram emblemáticas pela luta de seus estudantes por uma maior participação política; da mesma forma, os debates em que criticam a televisão e afirmam que existem na cidade e também no País muitas outras tribos, diferentes das mostradas na TV, e que se afirmam pela busca da criatividade e da participação coletiva - como os grupos de música e de dança, que se unem exatamente em nome de uma expressão artística. Essa demanda aparece também, esporádica e espasmodicamente, em alguns produtos da TV brasileira e de outros países ${ }^{16}$.

15 Eles se referem ao colégio apelidado carinhosamente de "Julinho", o Colégio Estadual 25 de Julho". Ver, a propósito, a dissertação de mestrado de Eliane Dable de Mello, sobre os jovens dessa escola de Porto Alegre (Mello, 2003).

${ }^{16}$ Mais recentemente, desde 2006, após o período da pesquisa, a Rede Globo inaugurou uma série de reportagens, intitulada Central da Periferia, apresentadas pela atriz Regina Casé, em que várias comunidades pobres, em todo o Brasil e em outros países, aparecem em suas manifestações culturais mais criativas - e não na repetitiva situação de violência, morte, pobreza e fome. 
Imagino que um dos trabalhos de estudiosos de educação e comunicação poderia ser o de apontar essas fissuras na cultura midiática de nosso tempo, seja a partir da análise de produtos dos diferentes meios de comunicação, seja a partir de estudos de recepção, especialmente com crianças e jovens ${ }^{17}$.

Descrevi e discuti, neste texto, modos pelos quais grupos jovens de camadas médias e baixas da população, em Porto Alegre, se relacionam com produtos televisivos a elas dirigidos. Especificamente, tratei de estratégias de construção de "outros", de diferentes, as quais emergem na fala de jovens de 15 a 25 anos, diante da TV. Trata-se de falas mestiças, complexas, plenas de perplexidade e dúvidas, formuladas por dentro de uma sociedade em que vigora a moral do espetáculo e a lógica do entretenimento. Alguns achados importantes foram discutidos: a) a televisão é parte fundamental da vida cotidiana dos jovens, como necessidade, lazer e companhia, mas também como fonte permanente de crítica à sociedade e à própria mídia; pode-se dizer que a TV funcionaria para eles como uma verdadeira "mãe cultural"; b) a televisão também funcionaria como um espaço igualitário e a democrático, justamente num país como o Brasil, em que são tão evidentes e sérias as muitas desigualdades sociais; c) o próprio tema da mídia, nos debates, mobilizou os jovens a vê-la como lugar de "manipulação"; mas a experiência cotidiana de assistir à TV, especialmente de debatê-la, desenvolveu nesses jovens uma espécie de habilidades críticas diante das diferentes medias; d) a TV parece ter uma significativa importância no complexo processo de "classificação do outro"; os depoimentos mostraram diferentes de tipos físicos, tipos de corpos jovens - considerados "aceitáveis" (por exemplo, os corpos jovens belos e magros), e aqueles corpos que "deveriam" ser excluídos; e) finalmente, o fato de debater sobre materiais da mídia (especialmente da televisão), produziu efeitos pedagógicos importantes - como a possibilidade de imaginar, com esses jovens, outros modos de existência na contemporaneidade, para esses grupos.

Certamente, restam ainda muitas outras indagações, para novas pesquisas, como estas, por exemplo: estariam os jovens e as crianças de nosso tempo, em cada um de nossos países, sendo construídos como "outros" que, paradoxalmente, amamos e rejeitamos? Como isso estaria ocorrendo? E de que modo a mídia se associaria aos educadores e à sociedade mais ampla, no sentido de nomear e classificar esses "outros" jovens?

Michel Foucault e Hannah Arendt alimentaram a maior parte de nossas análises, e é a partir deles que afirmamos a necessidade de não abandonar a discussão política em relação ao que nossa sociedade tem proposto que sejamos - nós, nossa vida, nossos corpos, nossas formas de ser jovem. Mas junto a essa análise que leva em consideração o poder e os modos de sujeição na cultura, buscamos mostrar que as inquietações de homens e mulheres jovens - sobre si mesmos, sobre o aprendizado que percebem em si a respeito das classificações de si e dos outros - podem ser tratadas como uma possibilidade de ação política, de exercício sobre si mesmo, visibilidade, mesmo que tênue, de um modo de subjetivação para além dos poderes e sujeições contemporâneos. A pesquisa, enfim, concluiu que a mídia não ensina nem dita "tudo" para os jovens. Existem rupturas, fissuras, abertas pelos próprios materiais e discursos midiáticos, possibilidades inesperadas de construir a si mesmo como sujeitos, apesar de todas as normas e regulações, próprias dos meios de comunicação.

Tanto nos produtos da mídia como nos usos que se faz deles, parece emergir não só um desejo de pensar o momento em que vivemos, como de lembrar que podemos fazer de nossas vidas uma arte: arte que diz respeito a pensar sobre si mesmo, cuidar de si, preparar-se para viver cada dia pois, como nos ensinaram filósofos antigos, nossa vida inteira é uma prova. Sendo assim, temos que nos preparar, todos os dias, equipando-nos para qualquer tipo de acontecimento ou imprevisto. Estudar a mídia e o que seus produtos nos propõem como modos de existência - no caso, modos de existência jovem - constituiria, à maneira de Foucault, uma

17 Ver, a respeito, algumas propostas sobre práticas de pesquisa e de intervenção na escola, a partir de estudos das imagens midiáticas, em Fischer, 1996; 2002; 2003. 
possibilidade de participar da elaboração de uma história do que fizemos de nós mesmos para sermos o que somos na atualidade. Ou seja, podemos descrever como se vão tecendo - nas construções da mídia e nas interações de diferentes públicos com essas produções - algumas formas específicas de ser e estar no mundo e neste País.

\section{Referências}

Abramo, H. W. (2005). Condição juvenil no Brasil contemporâneo. In: H. W. Abramo \& P. P. M. Branco (orgs.). Retrato da juventude brasileira São Paulo: Fundação Perseu Abramo / Instituto Cidadania .

Abramo, H., Freitas, M.V. \& Sposito, M. P. (orgs.). (2000). Juventude em debate. São Paulo: Cortez /Ação Educativa.

Arendt, H. (2000). A condição bumana. Rio de Janeiro: Forense.

Costa, J. F. (2004). O vestígio e a aura. Rio de Janeiro: Garamond.

Costa, J. F. (1999). Raz̃ões públicas, emoções privadas. Rio de Janeiro, Rocco.

Debord, G. (2002). A sociedade do espetáculo. Rio de Janeiro: Contraponto.

Derrida, J. \& Roudinesco, E. (2004). De que amanhã... diálogo. Rio de Janeiro: Zahar.

Fischer, R. M. B. (1996) Adolescência em discurso: mídia e produção de subjetividade. (1996). Tese de Doutorado. Universidade Federal do Rio Grande do Sul. Programa de Pós-Graduação em Educação, Porto Alegre.

Fischer, R. M. B. (2001). Mídia e educação da mulher: sobre modos de enunciar o feminino na TV. Revista Estudos Feministas, v. 9, n. 2, pp. 586-599.

Fischer, R. M. B. (2005a). Mídia e educação: em cena, modos de existência jovem. Educar em revista, n. 26, pp. 17-38.

Fischer, R. M. B. (2005b). Mídia, juventude e reinvenção do espaço público. Relatório final de pesquisa. Universidade Federal do Rio Grande do Sul. Faculdade de Educação, Porto Alegre.

Fischer, R. M. B. (1993). O mito na sala de jantar. Discurso infanto-juvenil sobre televisão. Porto Alegre: Movimento.

Fischer, R. M. B. (2002). Problematizações sobre o exercício de ver: mídia e pesquisa em educação. Revista Brasileira de Educação, n 20, pp. 83-94.

Fischer, R. M. B. (2000). Técnicas de si na TV: a mídia se faz pedagógica. Educação Unisinos, v. 4, n. 7, pp. 111-139.

Fischer, R. M. B. (2006). Televisão \& educação: fruir e pensar a TV. Belo Horizonte: Autêntica.

Foucault, M. (1986). A arqueologia do saber. Rio de Janeiro: Graal.

Foucault, M. (2004). A bermenêutica do sujeito. São Paulo: Martins Fontes.

Foucault, M. (1990). História da sexualidade I. A vontade de saber. Rio de Janeiro: Graal.

Foucault, M. (2001). Os anormais. São Paulo: Martins Fontes.

Foucault, M. (1995). O sujeito e o poder. In: H. Dreyfus \& P. Rabinow. Michel Foucault, uma trajetória filosófica. Para além do estruturalismo e da hermenêutica. Rio de Janeiro: Forense, pp. 231-249.

Foucault, M. (1991). Vigiar e punir. Petrópolis: Vozes.

Kehl, M. R. (2004). Três observações sobre os reality shows. In: E. Bucci \& M. R. Kehl. Videologias. São Paulo: Boitempo, pp. 165-173.

Larrosa, J. (2004). Educação e diminuição. In: __. Linguagem e educação depois de Babel. Belo Horizonte: Autêntica, pp. 265-294.

Mello, E. D. (2004) .Juventude e utopia: Experiências entre os muros de uma escola pública. Dissertação de Mestrado. Universidade Federal do Rio Grande do Sul, Instituto de Psicologia, Porto Alegre.

Sarlo, B. (1997a). Cenas da vida pós-moderna: intelectuais, arte e videocultura na Argentina. Rio de Janeiro: UFRJ.

Sarlo, B. (1997b). Paisagens imaginárias. São Paulo: EDUSP. 
Sennett, R. (2001). O declínio do homem público. As tiranias da intimidade. São Paulo: Cia. das Letras. Skliar, C. (2003). Pedagogia (improvável) da diferença. E se o outro não estivesse aí? Rio de Janeiro:

DP\&A.

Souza, J. (2003). A construção social da subcidadania. Belo Horizonte: UFMG.

Zizek, Slavoj. A paixão pelo real (Entrevista a Vladimir Safatle). Folha de S. Paulo. Caderno Mais! São Paulo, 30/11/2003, pp. 6-7.

\section{Dados Biográficos da Autora}

Rosa Maria Bueno Fischer é doutora em Educação, e professora da Universidade Federal do Rio Grande do Sul (UFRGS) no Curso de Pedagogia e no Programa de Pós-Graduação em Educação. É editora da revista Educação \& Realidade, da UFRGS, e autora dos livros O mito na sala de jantar: discurso infanto-juvenil sobre televisão e Televisão \& Educação: fruir e pensar a TV. A tua como pesquisadora do CNPq, membro do Comitê Assessor da CAPES e membro do Comitê Científico da ANPED. Tem experiência na área de Educação e da Comunicação, com ênfase em Sociologia e Filosofia da Cultura, estudos foucaultianos e pesquisas sobre mídia, juventude e processos de subjetivação.Sua pesquisa mais recente trata das relações entre memória cultural, alteridade e juventude.

Endereço para correspondência: rosabfischer@terra.com.br 


\title{
Arquivos $\mathbf{A}_{\text {nalíticos de }} \mathbf{P}_{\text {olíticas }} \mathbf{E}_{\text {ducativas http://epaa.asu.edu }}$ Editores
}

\author{
Gustavo E. Fischman Arizona State University \\ Pablo Gentili Universidade do Estado do Rio de Janeiro \\ Asistentes editoriales: Rafael O. Serrano (ASU) \& Lucia Terra (UBC)
}

$\begin{array}{ll}\text { Hugo Aboites } & \text { Armando Alcántara Santuario } \\ \text { UAM-Xochimilco, México } & \text { CESU, México } \\ \text { Claudio Almonacid Avila } & \text { Dalila Andrade de Oliveira } \\ \text { UMCE, Chile } & \text { UFMG, Brasil } \\ \text { Alejandra Birgin } & \text { Sigfredo Chiroque } \\ \text { FLACSO-UBA, Argentina } & \text { IPP, Perú } \\ \text { Mariano Fernández Enguita } & \text { Gaudêncio Frigotto } \\ \text { Universidad de Salamanca. España } & \text { UERJ, Brasil } \\ \text { Roberto Leher } & \text { Nilma Lino Gomes } \\ \text { UFRJ, Brasil } & \text { UFMG, Brasil } \\ \text { Pia Lindquist Wong } & \text { María Loreto Egaña } \\ \text { CSUS, USA } & \text { PIIE, Chile } \\ \text { Alma Maldonado } & \text { José Felipe Martínez Fernández } \\ \text { University of Arizona, USA } & \text { UCLA, USA } \\ \text { Imanol Ordorika } & \text { Vanilda Paiva } \\ \text { IIE-UNAM, México } & \text { UERJ, Brasil } \\ \text { Miguel A. Pereyra } & \text { Mónica Pini } \\ \text { Universidad de Granada, España } & \text { UNSAM, Argentina } \\ \text { Romualdo Portella de Oliveira } & \text { Paula Razquin } \\ \text { Universidade de São Paulo, Brasil } & \text { UNESCO, Francia } \\ \text { José Ignacio Rivas Flores } & \text { Diana Rhoten } \\ \text { Universidad de Málaga, España } & \text { SSRC, USA } \\ \text { José Gimeno Sacristán } & \text { Daniel Schugurensky } \\ \text { Universidad de Valencia, España } & \text { UT-OISE Canadá } \\ \text { Susan Street } & \text { Nelly P. Stromquist } \\ \text { CIESAS Occidente,México } & \text { USC, USA } \\ \text { Daniel Suárez } & \text { Antonio Teodoro } \\ \text { LPP-UBA, Argentina } & \text { Universidade Lusófona, Lisboa } \\ \text { Jurjo Torres Santomé } & \text { Lílian do Valle } \\ \text { Universidad de la Coruña, España } & \text { UERJ, Brasil } \\ & \end{array}$




\section{EDUCATION POLICY ANALYSiS ARCHIVES http://epaa.asu.edu}

\section{Editor: Sherman Dorn, University of South Florida}

Production Assistant: Chris Murrell, Arizona State University

General questions about appropriateness of topics or particular articles may be addressed to the Editor, Sherman Dorn, epaa-editor@shermandorn.com.

\section{Editorial Board}

\begin{tabular}{|l|l|}
\hline Noga Admon & Jessica Allen \\
\hline Cheryl Aman & Michael W. Apple \\
\hline David C. Berliner & Damian Betebenner \\
\hline Robert Bickel & Robert Bifulco \\
\hline Anne Black & Henry Braun \\
\hline Nick Burbules & Marisa Cannata \\
\hline Casey Cobb & Arnold Danzig \\
\hline Linda Darling-Hammond & Chad d'Entremont \\
\hline John Diamond & Amy Garrett Dikkers \\
\hline Tara Donohue & Gunapala Edirisooriya \\
\hline Camille Farrington & Gustavo Fischman \\
\hline Chris Frey & Richard Garlikov \\
\hline Misty Ginicola & Gene V Glass \\
\hline Harvey Goldstein & Jake Gross \\
\hline Hee Kyung Hong & Aimee Howley \\
\hline Craig B. Howley & William Hunter \\
\hline Jaekyung Lee & Benjamin Levin \\
\hline Jennifer Lloyd & Sarah Lubienski \\
\hline Susan Maller & Les McLean \\
\hline Roslyn Arlin Mickelson & Heinrich Mintrop \\
\hline Shereeza Mohammed & Michele Moses \\
\hline Sharon L. Nichols & Sean Reardon \\
\hline A.G. Rud & Lorrie Shepard \\
\hline Ben Superfine & Cally Waite \\
\hline John Weathers & Kevin Welner \\
\hline Ed Wiley & Terrence G. Wiley \\
\hline Kyo Yamashiro & Stuart Yeh \\
\hline
\end{tabular}

